\title{
PENEGAKAN HUKUM PIDANA DIBIDANG LINGKUNGAN HIDUP: PEMIDANAAN BERBASIS KONSERVASI LINGKUNGAN HIDUP
}

\section{Ryan Akbar Fitriadi}

Universitas Islam Indonesia (UII) Yogyakarta, Indonesia

Email: akbarryan113@gmail.com

\begin{abstract}
Abstrak
Peraturan perundang-undang berfungsi untuk mengatur kehidupan warga negara dalam menciptakan keamanan dan ketertiban dan juga memiliki hubungan dengan penegakan hukum terutama dalam penegakan hukum pidana. Permasalahan yang diangkat dalam penelitian ini, pertama, Pertanggungjawaban Pidana Lingkungan Hidup Dalam Perspektif Undang-Undang Perlindungan dan Pengelolaan Lingkungan Hidup, Kedua, Bagaimana Sistem Pemidanaan Dalam Tindak Pidana Bidang Lingkungan Hidup Berbasis Konservasi Lingkungan Hidup. Penelitian ini bertujuan untuk mengetahaui pertanggungjawaban dan sistem pemidanaan dalam tindak pidana di bidang lingkungan hidup berbasis konservasi lingkungan hidup. Penelitian ini merupakan penelitian hukum yuridis-normatif dengan metode pengumpulan data studi pustaka dan analisis secara deskriptif-kualitatif. Hasil penelitian ini yakni, Terdapat kelemahan norma dan sanksi dalam peraturan lingkungan hidup sebagaimana dalam UUPPLH Nomor 32 Tahun 2009, yang mana tidak menggambarkan secara jelas mengenai tujuan pemidanaan yang dapat dijadikan patokan dalam menetapkan sanksi pidana yang dilandasi dengan ide-ide dasar. Pengaturan jenis sanksi demikian tanpa pengaturan secara alternative akan berdampak dalam praktek pemidanaan berupa tuntutan dan penjatuhan pidana umum sebagaimana diatur dalam KUHP, belum menyentuh tujuan hukum lingkungan itu sendiri yang mana berfungsi sebagai acuan pemanfaatan dan pencadangan sumber daya alam serta pelestarian lingkungan hidup.
\end{abstract}

Kata Kunci: penegakan hukum pidana lingkungan; berbasis konservasi lingkungan hidup

\section{Abstract}

The laws and regulations are based on creating the lives of citizens in the creation of security and order and also the relationship with the law. The house that was optimized in this study, first, Per deviation of Environmental Criminal In Perspective of Environmental Protection and Management Law, Second, How The Criminal System In The Field of Environmental Crime Conservation of Environment Conservation. This research is ind as an idea to investigate the perkol and criminalization system in the field of environmental conservation-based environment. This research is a juridical-normative research with the method of collecting library study data and descriptive-qualitative analysis. The result of this study is, elements of norms and in environmental regulations so that in uupplh No.

\begin{tabular}{ll}
\hline How to cite: & Akbar, Ryan, Fitriadi (2021) Penegakan Hukum Pidana Dibidang Lingkungan Hidup: Pemidanaan \\
& Berbasis Konservasi Lingkungan Hidup, Syntax Idea, 3(7). https://doi.org/10.36418/syntax- \\
& idea.v3i7.1374 \\
E-ISSN: & 2684-883X \\
Published by: & Ridwan Institute
\end{tabular}


32 of 2009, which is not so flat which is good about the purpose of being a place to live in self-determined criminal which is with basic ideas. The regulation of what kind of regulation is likely to have an impact in the practice of criminalization and general criminal prosecution where in the Criminal Code, not yet the purpose of environmental law itself which threatens as a reference and backup of natural resources and the environment.

Keywords: criminal law enforcement; based on environmental conservation

\section{Pendahuluan}

Undang-Undang Nomor 32 Tahun 2009 tentang Perlindungan dan Pengelolaan Lingkungan Hidup (UU PPLH) masih belum dikatakan sempurna seperti yang masyarakat ataupun civitas akademisi harapkan, akan tetapi Undang-Undang tersebut merupakan hukum lingkungan yang cukup baik yang dimiliki Indonesia saat ini dikarenakan cukup komprehensif muatannya yang mana mengatur berbagai hal yang mana terkait dengan mengatur berbagai macam upaya-upaya berbagai bentuk urusan terkait lingkungan hidup termasuk perencanaan, pemanfaatan, pengendalian, pengawasan sampai dengan penegakan hukum lintas sektor, yang mana upaya salah satu upaya penegakan hukum tersebut adalah pada upaya penegakan hukum pidana berupa perlindungan dan kepastian hukum pada lingkungan hidup dengan diaturnya sanksi tambahan berupa pemulihan fungsi lingkungan dan dalam Undang-Undang 32 Tahun 2009 ini juga telah memuat pertanggungjawaban pidana korporasi (Daniel, Hawari, and Handayani 2020).

Dalam memahami konsep hukum pidana lingkungan adalah memahami konsep hukum pidana itu sendiri. Hal ini karena hukum pidana lingkungan merupakan bagian dari hukum pidana, sekalipun aspek hukum lingkungan juga dikaji didalamnnya, Moeljatno dalam (Ali 2020) mengartikan hukum pidana sebagai bagian dari keseluruhan hukum yang berlaku di suatu negara, yang mengadakan dasar-dasar dan aturan-aturan untuk:

1. Menentukan perbuatan-perbuatan yang tidak boleh dilakukan, yang dilarang dengan disertai ancaman atau sanksi pidana tertentu bagi siapa saja yang melanggarnya;

2. Menentukan kapan dan dalam hal apa kepada mereka yang telah melakukan larangan- larangan itu dapat dikenakan atau dijatuhi pidana sebagaimana yang telah diancamkan;

3. Menentukan dengan cara bagaimana pengenaan pidana itu dapat dilaksanakan apabila orang yang diduga telah melanggar ketentuan tersebut.

Penegakan hukum pidana lingkungan bertujuan untuk mewujudkan undangundang 32 Tahun 2009 tentang perlindungan dan pengelolaan lingkungan hidup (UUPLH), maka demikian agar terealisasinya undang-undang tersebut dapat mengatur berbagai bentuk yang terkait dengan lingkungan hidup seperti, perencanaan, pemanfaatan, pengendalian, pengawasan dan juga terdapat penegakan hukum lintas, dan tidak kalah penting penggunaan sistem pemidanaan lingkungan hidup mengacu pada penerapan asas ultimum remedium, pembuktianya pun tidak perlu lagi memasukkan 
unsur melawan hukumnya, dan pidana tambahan berupa penanggulangan dan pemulihan lingkungan hidup (penutupan usaha dan/ atau kegiatan), serta penerapan sanksi minimum maksimum untuk bertujuan menghindari adanya disparitas (Raynaldo Sembiring, Marsya M.Handayani 2019).

Kebijakan pertanggungjawaban pidana korporasi dalam perkara lingkungan yang mana merupakan penentuan wewenang yang rasional oleh masyarakat untuk mengcontrol suatu kejahatan, maka demikian untuk memformulasi suatu kebijakan hukum pidana tentu mempunyai korelasi terhadap kebijakan sosial, artinya forumulasi kebijakan hukum pidana tidak terlepas dari kebijakan sosial yang mana harus memadukan antara penggunaan sarana hukum pidana dan sarana diluar hukum pidana, serta mempertimbangkan efektivitas dan proporsionalitas terhadap tujuan akhir yang hendak dicapai. ana lingkungan hidup di Indonesia (Daniel, Hawari, and Handayani 2019).

Jika melihat bentuk sistem pertanggungjawaban pidana di dalam UUPPLH berdasarkan atas asas kesalahan, disamping itu bentuk pertanggungjawaban tersebut juga diadobli oleh sistem pertanggungjawaban pidana korporasi. Beranjak dari sistem pertanggungjawaban pidana yang berdasarkan asas kesalahan, dimana undang-undang telah merumuskan frasa, seperti "dengan sengaja", "karena kelalaian", "melakukan pembukaan lahan dengan cara membakar", "melepaskan dan/atau mengedarkan" dan "melakukan dumping". Unsur objektif yang dirumuskan dengan menggunakan kalimat aktif biasanya mengarah kepada kesengajaan meskipun frasa "dengan sengaja" tidak dirumuskan secara eksplisit dalam rumusan pasal. Sementara itu, untuk sistem pertanggungjawaban pidana korporasi, bisa dilihat dari rumusan Pasal 116 (1) UU PPLH yang menyatakan bahwa "apabila tindak pidana lingkungan hidup dilakukan oleh, untuk, atau atas nama badan usaha, tuntutan pidana dan sanksi pidana dijatuhkan kepada (1) badan usaha; dan/atau (2) orang yang memberi perintah untuk melakukan tindak pidana tersebut atau orang yang bertindak sebagai pemimpin kegiatan dalam tindak pidana tersebut"(Ali 2020).

\section{Metode Penelitian}

Penelitian ini merupakan penelitian hukum normatif dengan pendekatan penelitian yang digunakan adalah pendekatan perundang-undangan (statute approach). Bahan hukum dalam penelitian ini bahan hukum primer yang terdiri dari bahan-bahan hukum yang mempunyai kekuatan mengikat sebagai landasan utama yang dipakai dalam rangka penelitian ini, yang terdiri dari: Undang-Undang Dasar Negara Republik Indonesia Tahun 1945, Kitab Undang-Undang Hukum Acara Pidana. Bahan hukum sekunder yang terdiri dari jurnal, buku, dan penelitian yang relevan. Bahan hukum tersier berupa kamus hukum. Untuk menguatkan bahan hukum tersebut. Metode analisis yang digunakan deskriptif-kualitatif untuk menjawab rumusan masalah. 


\section{Hasil dan Pembahasan}

\section{Pertanggungjawaban Pidana Lingkungan Hidup dalam Perspektif Undang - Undang Perlindungan dan Pengelolaan Lingkungan Hidup}

Arah dari sistem pemidanaan pada kejahatan lingkungan tertuju pada upaya untuk menuntun masyarakat, pengusaha, dan pemerintah agar dapat memelihara lingkungan hidup. Selain dari pada itu, sistem pemidanaan yang dimiliki UUPPLH tentu mencegah dan menghalangi pelaku yang melakukan perilaku yang tidak bertanggungjawab terhadap lingkungan hidup (Muhammad Erwin 2015).

Adapun norma baru yang sangat penting tentang perlindungan hukum atas tiap orang yang memperjuangka hak atas lingkungan hidup, kewenangan Pejabat Penyidik Pegawai Negeri Sipil (PPNS) dan penciptaan delik-delik materiil baru. Pertama, UUPPLH yang secara tegas dan jelas mengadopsi asas-asas yang terkandung dalam deklarasi Rio 1982, yaitu asas-asas tanggungjawab negara, keterpaduan, kehati-hatian, keadilan, pencemar membayar, partisipatif dan kearifan lokal. Kedua, UUPPLH, khususnya dengan Pasal 66 UUPPLH sangat maju dalam memberikan perlindungan hukum kepada orang yang memperjuangkan hak atas lingkungan hidup dari kemungkinan tuntutan pidana dan perdata. Ketiga, UUPPLH memberikan perubahan dalam bidang kewenangan penyidikan dalam perkaraperkara lingkungan. Berdasarkan Pasal 6 ayat (1) b Undang-Undang Hukum Acara Pidana (KUHAP), penyidik adalah pejabat Polisi Negara Republik Indonesia dan pejabat Pegawai Negeri Sipil tertentu diberikan wewenang khusus oleh UndangUndang. UUPPLH merupakan salah satu Undang-Undang sebagaimana dimaksud Pasal 6 ayat (1) yang menjadi dasar bagi keberadaan PPNS sebagaimana dirumuskan dalam Pasal kewenangan Polri selain sebagaimana dirumuskan dalam Pasal kewenangan Polri selain sebagaimana disebutkan dalam Pasal 7 ayat (1) KUHAP (Joni 2020).

a. Delik Dalam Tindak Pidana Lingkungan Hidup.

Pertanggungjawaban pidana dalam Undang-Undang Lingkungan hidup berupa tanggung jawab mutlat (strick liability), hal ini dapat ditemukan dalam rumusan redaksional Pasal 88 berbunyi: "Setiap orang yang tindakannya, usahanya, dan/atau kegiatannya menggunakan B3, menghasilkan dan/atau mengelola limbah B3, dan/atau yang menimbulkan ancaman serius terhadap lingkungan hidup bertanggungjawan mutlak atas kerugian yang terjadi tanpa perlu pembuktian unsur kesalahan" (Amrani 2019).

Namun demikian, delik lingkungan yang fleksibel ini ternyata menambrak prinsip asas hukum pidana itu sendiri

Rumusan delik lingkungan yang fleksibel ternyata melanggar prinsip nullum crime, nulla poena sine lege certa (lex certa) yang menghendaki agar delik dirumuskan secara jelas dan tidak bersifat multitafsir. Rumusan delik yang jelas juga berhubungan dengan fungsi perlindungan dari asas legalitas yang bermakna bahwa Undang-Undang pidana melindungi rakyat dari kekuasaan pemerintah 
tanpa batas. Rumusan delik lingkungan yang jelas (lex certa) selain sebagai perlindungan hukum.

Delik-delik dalam UUPPLH yang dikategorikan sebagai administrative dependent of environmental criminal law administrative dependent crimes awalnya merupakan pelanggaran administrasi. Tujuan pecantuman ancaman sanksi pidana dalam pelanggaran administrasi adalah untuk memperkuat sanksi adminstratif. Keterlibatan hukum pidana ke dalam pelanggaran administratif hanya bersifat komplementer karena eksistensinya hanya sebagai penunjang penegakan norma yang ada dibidang hukum administrasi. Oleh karena itu, hukum pidana ditempatkan sebagai sarana terakhir (ultimum remidium) dalam upaya menanggulangi pelanggaran-pelanggaran administratif tersebut. Hukum pidana baru ditempatkan sebagai primum remedium jika delik yang dilanggar terkait administrative independent crimes.

Secara normatif, fungsionalisasi hukum pidana sebagai ultimum remedium dalam UUPPLH diatur dalam Pasal 78 dan Pasal 100 ayat (2). Pasal 78 menegaskan bahwa bentuk-bentuk sanksi administratif, seperti terguran tertulis, paksaan pemerintah, pembekuan izin lingkungan, dan pencabutan izin lingkungan tidak membebaskan penanggungjawan usaha dan/atau kegiatan dari tanggungjawab pemulihan dan pidana. Dalam konteks delik lingkungan, penerapan hukum pidana sebagai ultimum remedium diatur dalam Pasal 100 ayat (2) dan hanya berlaku terhadap pelanggaran Pasal 100 ayat (1) yang menyataka bahwa, "Setiap orang yang melanggar baku mutu air limbah, baku mutu emisi, atau baku mutu gangguan dipidana, dengan pidana penjara paling lama 3 (tiga) tahun dan denda paling banyak Rp.3.000.000.000,- (tiga milyar rupiah)”.

Tindak pidana dalam Pasal 100 ayat (1) tersebut hanya dapat dikenakan apabila sanksi administratif yang telah dijatuhkan tidak dipatuhi atau pelanggaran dilakukan lebih dari satu kali. Berdasarkan ketentuan pasal ini, fungsionalisasi hukum pidana sebagai ultimum remedium dalam UU PPLH hanya dapat diberlakukan apabila memenuhi tiga syarat, yaitu; 1) hanya berlaku terhadap pelanggaran delik dalam Pasal 100 ayat (1); 2) hanya berlaku apabila sanksi administrartif yang telah dijatuhkan tidak dipatuhi; dan 3) pelaku delik telah melakukan pelanggaran terhadap delik dalam Pasal 100 ayat (1) lebih dari satu kali. Apabila pelaku baru satu kali melakukan delik tersebut, penyelesaiannya menggunakan mekanisme hukum administrasi (Ali 2020).

secara singkat teori yang mendasari penggunaan primum remedium pada sebagian besar pasal, dan bagaimana ultimum remedium diakomodir. Sebagaimana dijelaskan bahwa tujuan pemidanaan dalam UU No. 32 Tahun 2009 adalah untuk menimbulkan efek jera, baik bagi pelaku maupun masyarakat umum; dan penggunaan ultimum remedium haruslah sesuai dengan tujuan tersebut. Efek jera hanya dapat ditimbulkan apabila sanksi yang dikenakan pada pelanggar diperberat sehingga sanksi harus lebih besar daripada kerusakan yang timbul. Dalam hal ini, Naskah Akademis mengutip Faure dengan rumusan sebagai 
berikut: (Raynaldo Sembiring, S.H., Yustisia Rahman, S.H., Elizabeth Napitupulu, S.H., Margaretha Quina, S.H. 2014)

$$
\begin{array}{r}
\text { Sanksi = B (Potensi Bahaya yang Ditimbulkan } \\
\text { D (Probalitas dilakukan Deteksi) }
\end{array}
$$

Semakin kecil kemungkinan dilakukannya deteksi, maka dibutuhkan sanksi yang besar. Lebih lanjut, dinyatakan bahwa sanksi hukum perdata dan administratif tidak cukup memberikan efek jera, terlebih lagi ditambah dengan kesulitan Indonesia dalam melakukan deteksi terhadap pelanggaran ketentuan lingkungan hidup, baik karena kelemahan kelembagaan, kekurangan SDM serta sarana dan prasana lainnya maupun karena masih dianutnya paradigma propembangunan. Oleh karena itu, dalam hal potensi bahaya yang besar, maka diperlukan penegakan hukum pidana yang tidak terbelenggu asas ultimum remedium (Raynaldo Sembiring, S.H., Yustisia Rahman, S.H., Elizabeth Napitupulu, S.H., Margaretha Quina, S.H. 2014).

Namun penting untuk dilihat keterkaitannya, diaman Pasal 100 terkait sangat erat dengan baku mutu effluent yang merupakan instrument pencegahan pencemaran lingkungan. Baku mutu air limbah, baku mutu emisi, dan baku mutu gangguan secara tegas diatur secara kuantitatif dalam perundang-undangan turunan, dan pelanggarannya terlebih dahulu merupakan rezim penegakan hukum administrasi. Sementara itu, Pasal-Pasal pidana yang berdasarkan asas premum remedium tidak perlu menempuh penegakan hukum administrasi dulu agar dapat ditindaklanjuti (Raynaldo Sembiring, S.H., Yustisia Rahman, S.H., Elizabeth Napitupulu, S.H., Margaretha Quina, S.H. 2014).

UUPPLH telah menganut vicarious liability, yaitu sebuah bentuk pertanggungjawaban dalam hukum pidana dalam sistem hukum anglo saxon yang tidak mensyaratkan adanya unsur mensrea atau kesalahan dalam sebuah tindak pidana. Kalau interpretasi ini yang dianut, maka terjadi penyimpangan dari asas tiada hukuman tanpa kesalahan yang dianut hukum pidana di Indonesia. Interpretasi lainnya adalah meski rumusan-rumusan delik formil dalam UUPPLH mencantumkan secara tegas unsur mensrea atau kesalahan, secara tersirat dianggap ada karena delik-delik itu umumnya terkait dengan perbuatan aktif manusia yang pasti didorong oleh kesadaran alam pikiran si pelaku, misalkan "memasukan limbah B3 ke dalam wilayah Negara Kesatuan Republik Indonesia", "Menyusun Amdal tanpa memiliki sertifikat kompeten", "menerbitkan izin lingkungan tanpa dilengkapi Amdal, RKL-RPL.” (Rahmadi 2019).

Kebijakan peraturan perundang-undangan yang sengaja didesain atau mungkin juga karena "kelalaian" untuk tidak dapat efektif mencegah atau menyelesaikan masalah lingkungan. Kelemahan ini dapat dilihat dari beberapa peraturan perundang-undangan lingkungan hidup yang cenderung bersifat pragmatis, rekatif, sectoral, parsial, dan berjangka pendek (Bram 2014). 
b. Pertanggungjawaban Korporasi Dalam Tindak Pidana Lingkungan Hidup.

UUPPLH mengakui korporasi sebagai subjek hukum pidana yang berbuat dan bertanggungjawab pidana. Pasal 116 UU PPLH mengatur sistem pemidanaan korporasi yang menyatakan jika tindak pidana lingkungan hidup dilakukan oleh, untuk, atau atas nama badan usaha, tuntutan, pidana dan sanksi pidana dapat ditujukan kepada:

1. Badan usaha,

2. Orang perorangan yang memberi perintah untuk melakukan tindak pidana tersebut atau orang yang bertindak sebagai pemimpin kegiatan dalam tindak pidana tersebut,

3. Badan usaha dan orang perorangan sama-sama dipidana.

Pasal 117 UU PPLH mengatur pemberatan pidana terhadap kasus pidana lingkungan yang dilakukan untuk dan atas nama korporasi, jika tuntutan pidananya diajukan kepada pemberi perintah atau pemimpin tindak pidana (manusia alamiah) sebagaimana diatur dalam Pasal 116 ayat (1) huruf b UU PPLH. Jadi, ketika seseorang melakukan tindak pidana lingkungan dan pelaku melakukan tindak pidana tersebut untuk dan atas nama korporasi, maka pidananya diperberat sepertiga dari ancaman pasal yang dilanggar.

Menarik dalam pengaturan pertanggungjawaban pidana korporasi dalam UUPPLH adaah pengaturan Pasal 118 UUPPLH. Pasal tersebut mengatur bahwa sanksi pidana yang dijatuhkan kepada badan usaha diwakilkan kepada pengurus yang berwenang mewakili di dalam dan diluar pengadilan (pelaku fungsional). Hal itu berarti dalam tindak pidana lingkungan selalu berakhir pada pemidanaan manusia alamiah saja, walaupun UU PPLH mengatur tentang pelaku korporasi. Sanksi yang memungkinkan bagi korporasi hanya pidana tambahan sebagaimana diatur dalam Pasal 119 UUPPLH (Wibisana, 2019). Rumusan ketentuan pasal 118 UUPPLH mirip dengan vicarious liability dalam sistem hukum anglo saxon (Joni 2020)

Dalam perihal pelaksanaan eksekusi dari putusan hakim tersebut diserahkan kepada jaksa dengan berkoordinasi kepada instansi yang bertanggung jawab di bidang perlindungan dan pengelolaan lingkungan hidup (Pasal 120 ayat (1) UU No. 32 Tahun 2009). Terhadap badan usaha/korporasi yang dijatuhi sanksi penempatan di bawah pengampuan dengan putusan pengadilan yang telah berkekuatan hukum tetap, maka kewenangan pengelolaanya diserahkan kepada pemerintah (Pasal 120 ayat (2) UU No. 32 Tahun 2009) (Muhammad Erwin 2015).

Oleh karena itu, adalah tepat, apabila jaksa berkoordinasi sebelum melaksanakan eksekusi agar tidak terjadi tumpang tindih dalam penegakan hukum atau diatuhkan sanksi dua kali untuk pelanggaran yang sama (Zairin Harahap 2020). Menurut Muladi dalam (Muhammad Erwin 2015), bentuk pertanggungjawaban korporasi dalam tindak pidana lingkungan ini hendaknya 
memerhatikan pula kecenderungan internasional dengan memerhatikan hal-hal sebagai berikut :

- Korporasi mencakup, baik badan hukum (legal entity) maupun nonbadan hukum seperti organisasi dan sebagainya;

- Korporasi dapat bersifat privat (private juridicial entity) dan dapat pula bersifat publik (public entity);

- Apabila diindentifikasikan, bahwa tindak pidana lingkungan dilakukan dalam bentuk organisasi, maka orang alamiah (managers, agents, employess) dan korporasi dapat dipidana, baik sendiri - sendiri maupun bersama - sama ( $b i-$ punishment provision);

- Terdapat kesalahan manajemen dalam korporasi dan terjadi apa yang dinamakan breach of a statutory or regulatory provision;

- Pertanggungjawaban badan hukum dilakukan terlepas dari apakah orang orang yang bertanggungjawab di dalam badan hukum tersebut berhasil diidentifikasi, dituntut dan dipidana;

- Segala sanksi pidana dan tindakan tindakan pada dasarnya dapat dikenakan pada korporasi, kecuali pidana mati dan pidana penjara;

- Penerapan sanksi pidana terhadap korporasi tidak menghapuskan kesalahan peorangan; serta

- Pemidanaan terhadap korporasi hendaknya memerhatikan kedudukan korporasi untuk mengendalikan perusahaan melalui kebijakan pengurus atau para pengurus (corporate executive officers) yang memiliki kekuasaan untuk memutuskan (power of decision) dan keputusan tersebut telah diterima oleh korporasi tersebut.

Ketentuan di atas memberikan beberapa implikasi hukum. Pertama, badan usaha tidak bisa lagi lepas dari tanggungjawab pidana jika melakukan perbuatan atau akibat dari perbuatan yang memenuhi kualifikasi tindak pidana lingkungan. Persoalannya adalah apa bentuk tanggungjawan pidana yang utama terhadap badan hukum. Bukankah sanksi pidana dalam Pasal 119 UUPPLH - 2009 adalah pidana tambahan, bukan pidana pokok kedua, sanksi pidana terhadap para pengurus, terutama yang memberi perintah atau pemimpin tindak pidana dikenakan sanksi pidana yang diperberat dengan sepertiga. Ketentuan ini berimlikasi bahwa para pengurus bertindak hati - hati agar perusahaan tidak melakukan tindak pidana lingkungan. Ketiga, pejabat administrasi negara, terutama pemberi izin dan pejabat berwenang di bidang pengelolaan dan perlindungan lingkungan hidup wajib melakukan tugas dan wewenangnya sesuai ketentuan yang berlaku. Hal ini penting, karena pejabat yang bersangkutan selain dapat dikenakan sanksi administrasi, juga diancam dengan sanksi pidana. Keempat, semua ketentuan tersebut berimplikasi terhadap penguatan penegakan hukum pidana (Akib 2014). Dengan berlakunya UUPLH memungkinkan penjatuhan sanksi hukum pidana terhadap korporasi termasuk pimpinan 
perusahaan (factual leader) atau pemberi perintah lainnya (instruction giver) dalam lingkungan korporasi bila terjadi tindak pidana lingkungan (Husin 2014).

c. Sistem Pemidanaan Dalam Tindak Pidana Bidang Lingkungan Hidup Berbasis Konservasi Lingkungan Hidup

Untuk merefleksikan peranan pembaruan hukum lingkungan Indonesia dalam mewujudkan tata kelola lingkungan yang baik dalam demokrasi ini, perlu merunut kembali peristiwa-peristiwa sejarah yang memperngaruhi perkembangan hukum lingkungan, baik dalam skala global muapun nasional atau domestik. Setidaknya, terdapat empat kelompok besar dari peristiwa ini, yaitu: 1) Peristiwa internasional dan perjanjian internasional; 2) kebijakan, peraturan perundang undangan dan peraturan lainnya di level nasional; 3) Landmark cases atau yurisprudensi; serta 4) inisiatif masyarakat sipil atau donor (Margaretha 2014).

Kriminalisasi terhadap kerusakan/pencemaran lingkungan perlu didasarkan pada model kriminalisasi berbasis kepentingan dan kerugian lingkungan, yaitu bahaya abstrak (abstract endangerment), bahaya nyata (concrete endangerment) dan kerusakan/pencemaran lingkungan yang serius (serios environmental pollution). Model abstract endangerment mengkriminalisasi kerusakan/pencemaran lingkungan secara tidak langsung yang hanya ditujukan kepada pelanggaran terhadap kewajiban-kewajiban administrasi yang tidak melibatkan kontak langsung antara bahan tercemar dengan lingkungan.

Model serious environmental pollution sudah melepaskan diri sepenuhnya dari ketergantungan administrasi hukum pidana. Seseorang sekalipun telah memiliki izin dari pejabat administrasi, tapi jika perbuatannya menimbulkan kerugian serius terhadap lingkungan, maka perbuatan tersebut tetap dikategorikan sebagai tindak pidana. Pertanggungjawaban Pidana Korporasi dalam Perkara Lingkungan Hidup Belum Berorientasi Pada Pemulihan (Ali 2019).

Sepanjang tahun 2010 sampai 2019 ditemukan setidaknya 8 kasus yang telah berkuatan hukum tetap maupun belum. Putusan-putusan tersebut dirangkum dalam tabel berikut ini: (Daniel, Hawari, and Handayani 2020)

Tabel 1

Ringkasan Perkara Pidana Lingkungan Hidup Korporasi Tahun 2010 - 2019

\begin{tabular}{|c|c|c|c|c|c|}
\hline No & Nama Perkara & $\begin{array}{l}\text { Tindak } \\
\text { Pidana }\end{array}$ & Tuntutan JPU & Putusan Hakim & Durasi \\
\hline 1 & $\begin{array}{l}\text { PT Adei Plantation } \\
\text { 1. } 228 / \text { Pid. Sus/2013/ PN. Plw } \\
\text { tanggal 9 September 2014 } \\
\text { 2. } 286 / \text { Pid.Sus/2014/PT. PBR } \\
\text { tanggal 9 Januari 2015 } \\
\text { 2042K/Pid.Sus/2015 tanggal } 14 \\
\text { maret 2016 }\end{array}$ & $\begin{array}{l}\text { Pasal } 99 \\
\text { UU } \\
32 / 2009\end{array}$ & $\begin{array}{l}\text { Pidana denda Sebesar Rp. } \\
5.000 .000 .000 .00\end{array}$ & $\begin{array}{l}\text { Pidana denda sebesar Rp. } \\
1.500 .000 .000 .00 \text { subsider } \\
5 \text { bulan kurugan kepada } \\
\text { Tan Kei Yoong }\end{array}$ & $\begin{array}{l}\text { Perkara } \\
\text { telah } \\
\text { didaftarkan } \\
\text { sejak } 24 \\
\text { desmber } \\
2013 \\
\text { dengan } \\
\text { durasi } 812 \\
\text { hari. }\end{array}$ \\
\hline & & & $\begin{array}{l}\text { Pidana Tambahan : } \\
\text { Perbaikan akibat tindak } \\
\text { pidana untik memulihkan } \\
\text { lahan yang rusak akibat } \\
\text { kebakaran lahan seluas } \\
\text { 40ha melalui pemberian } \\
\end{array}$ & $\begin{array}{l}\text { Pidana tambahan: } \\
\text { Perbaikan akibat tindak } \\
\text { pidana untuk memulihkan } \\
\text { lahan yang rusak akibat } \\
\text { kebakaran lahan seluas } 40 \\
\text { ha melalui pemberian }\end{array}$ & \\
\hline
\end{tabular}


Penegakan Hukum Pidana Dibidang Lingkungan Hidup: Pemidanaan Berbasis Konservasi Lingkungan Hidup

\begin{tabular}{|c|c|c|c|c|c|}
\hline No & Nama Perkara & $\begin{array}{l}\text { Tindak } \\
\text { Pidana }\end{array}$ & Tuntutan JPU & Putusan Hakim & Durasi \\
\hline & & & $\begin{array}{l}\text { kompos, dengan biaya } \\
\text { sebesar Rp. 15. 794.238. } \\
630.00\end{array}$ & $\begin{array}{l}\text { kompos, dengan biaya } \\
\text { sebesar Rp. 15.141. } 826 . \\
779.325 .\end{array}$ & \\
\hline 2 & $\begin{array}{ll}\text { PT. } & \text { Albasi Priangan Lestari : } \\
\text { 1. } & \text { 155/Pid. Sus/2013/ PN. } \\
& \text { CMS tanggal 4 September } \\
& 2013 \\
\text { 2. } & \text { 344/Pid/2013/PT BDG } \\
& \text { tangga } 18 \text { November } 2013 \\
\text { 3. } & \text { 814K/Pid. Sus/2014 } \\
& \text { tanggal 22 Oktober } 2014\end{array}$ & $\begin{array}{l}\text { Pasal } \\
100 \text { UU } \\
32 / 2009\end{array}$ & $\begin{array}{l}\text { Pidana denda sebesar Rp. } \\
350.000 .000 .00\end{array}$ & $\begin{array}{l}\text { Pidana denda Rp. } 1 . \\
000.000 .000 .00 \text { dengan } \\
\text { ketentuan apabila denda } \\
\text { tersebut tidak dibayarmaka } \\
\text { sebagian asset/harta PT. } \\
\text { Albasi Priangan Lestari, } \\
\text { disita dan dijual lelang } \\
\text { untuk sekedar cukup untuk } \\
\text { membayar jumlah denda } \\
\text { dimaksud }\end{array}$ & $\begin{array}{lr}\text { Perkara } & \\
\text { telah } & \\
\text { didaftar } & \\
\text { sejak } & 11 \\
\text { juni } & 2013 \\
\text { dengan } & \\
\text { durasi } & 591 \\
\text { hari. } & \end{array}$ \\
\hline 3 & 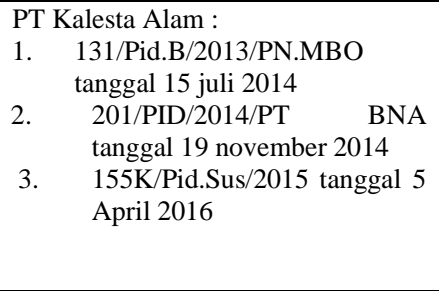 & $\begin{array}{l}\text { Pasal } \\
108 \text { UU } \\
32 / 2009\end{array}$ & $\begin{array}{l}\text { Pidana denda sebesar Rp. } \\
3.000 .000 .000 .00\end{array}$ & $\begin{array}{l}\text { Pidana denda sebesar Rp. } \\
3.000 .000 .000 .00\end{array}$ & $\begin{array}{l}\text { Perkara } \\
\text { telah } \\
\text { didaftarkan } \\
\text { sejak } 27 \\
\text { september } \\
2013 \\
\text { dengan } \\
\text { durasi } 922 \\
\text { hari. }\end{array}$ \\
\hline \multirow[t]{2}{*}{4} & $\begin{array}{ll}\text { PT Koyama Casting Indonesia : } \\
\text { 1. } & \text { 89/Pid.Sus/2014/PN.Krw } \\
& \text { tanggal 15 Desember 2014 } \\
\text { 2. } & \text { 112/Pid.Sus/2015/PT.bdg } \\
& \text { tanggal 20 mei 2015 } \\
\text { 3. } & \text { 2560K/Pid.Sus.LH/2015 } \\
& \text { tanggal 12 mei 2016 }\end{array}$ & $\begin{array}{l}\text { Pasal } \\
103 \text { UU } \\
32 / 2009\end{array}$ & $\begin{array}{l}\text { Menjatuhkan } \\
\text { terhadap terdakwa shigemi } \\
\text { koyama dengan pidana } \\
\text { penjara selama } 2 \text { tahun } \\
\text { penjara dengan perintah } \\
\text { agar terdakwa ditahan dan } \\
\text { membayar denda sebesar } \\
\text { Rp. 1.000.000.000.00 } \\
\text { subsidair } 6 \text { bulan kurungan }\end{array}$ & $\begin{array}{l}\text { Pidana denda sebesar Rp. } \\
1.000 .000 .000 .00 \text { dengan } \\
\text { ketentuan tersebut tidak } \\
\text { dibayar diganti dengan } \\
\text { perampasan aset PT KCI } \\
\text { oleh Penuntut Umum untuk } \\
\text { dijual lelang menutupi } \\
\text { denda sejumlah tersebut }\end{array}$ & $\begin{array}{l}\text { Perkara } \\
\text { telah } \\
\text { didaftarkan } \\
\text { sejak } 4 \text { april } \\
2014 \\
\text { dengan } \\
\text { durasi } 770 \\
\text { hari. }\end{array}$ \\
\hline & & & & $\begin{array}{l}\text { Pidana tambahan : } \\
\text { Memerintahkan kepada } \\
\text { terdakwa PT KCI } \\
\text { melakukan pengelolaan } \\
\text { limbah dengan badan usaha } \\
\text { yang mempunyai izin } \\
\text { dalam pengelolaan limbah } \\
\end{array}$ & \\
\hline
\end{tabular}


Ryan Akbar Fitriadi

\begin{tabular}{|c|c|c|c|c|c|}
\hline No & Nama Perkara & $\begin{array}{l}\text { Tindak } \\
\text { Pidana } \\
\end{array}$ & Tuntutan JPU & Putusan Hakim & Durasi \\
\hline \multirow{2}{*}{\multicolumn{2}{|c|}{ januari 2014}} & & & & $\begin{array}{l}\text { durasi } 713 \\
\text { hari (dari } \\
\text { putusan } \\
\text { tingkat } \\
\text { pertama) }\end{array}$ \\
\hline & & & $\begin{array}{l}\text { Pidana tambahan: } \\
\text { Menjatuhkan pidana } \\
\text { tambahan beruoa perbaikan } \\
\text { akibat tindak pidana yang } \\
\text { dalam pelaksanaannya } \\
\text { dalam pengawasan Badan } \\
\text { Lingkungan Hidup } \\
\text { Kabupaten Karawang }\end{array}$ & & \\
\hline \multirow[t]{2}{*}{6} & $\begin{array}{l}\text { PT Platindo Agro Subur : } \\
\text { 1/Pid.Sus - LH/2016/PN Rta tanggal } \\
26 \text { juli } 2016\end{array}$ & $\begin{array}{l}\text { Pasal } 99 \\
\text { ayat (1) } \\
\text { UU } \\
32 / 2009\end{array}$ & \begin{tabular}{lr}
\multicolumn{3}{l}{ Pidana denda sebesar Rp. } \\
2.000 .000 .000 .00 & apabila \\
pidana dengan & tidak \\
dibayar maka & harta \\
kekayaan/aset & korporasi \\
dirampas sesuai & peraturan \\
perundang - & undangan \\
yang berlaku & \\
\end{tabular} & $\begin{array}{lcc}\text { Pidana } & \text { denda } & \text { Rp. } \\
1.500 .000 .000 .00 & \end{array}$ & $\begin{array}{lr}\text { Perkara } & \\
\text { telah } & \\
\text { didaftarkan } \\
\text { sejak } \quad 28 \\
\text { maret } & 2016 \\
\text { dengan } \\
\text { durasi } & 120 \\
\text { hari } & \\
\end{array}$ \\
\hline & & & $\begin{array}{l}\text { Pidana tambahan: } \\
\text { Pewajiban mengerjakan } \\
\text { apa yang dilalaikan tanpa } \\
\text { hak yaitu melengkapi } \\
\text { sarana dan prasarana } \\
\text { pencegahan kebaran hutan } \\
\text { dan/atau lahan yang } \\
\text { memadai serat } \\
\text { memperbaiki managemen } \\
\text { sumber daya manusia } \\
\text { terkait pencegahan } \\
\text { kebakaran lahan/hutan dan } \\
\text { membuat dan merevisi } \\
\text { laporan terkait lingkungan } \\
\text { hidup yang menjadi } \\
\text { kewajiban terdakwa }\end{array}$ & $\begin{array}{l}\text { Pidana tambahan : } \\
\text { Menjatuhkan pidana } \\
\text { tambahan atau tindakan } \\
\text { tata tertib berupa pewajiban } \\
\text { mengerjakan apa yang di } \\
\text { lalaikan tanpa hak }\end{array}$ & \\
\hline \multirow[t]{2}{*}{7} & $\begin{array}{ll}\text { PT National Sago Prima: } \\
\text { 1. } & \text { 547/Pid.Sus/2014/PN.Bls } \\
& \text { tanggal } 19 \text { januari } 2015 \\
2 . & \text { 27/Pid.Susu/2015/PT } \\
& \text { tanggal } 1 \text { juni } 2015\end{array}$ & $\begin{array}{l}\text { Pasal } 99 \\
\text { ayat (1) } \\
\text { UU } \\
32 / 2009\end{array}$ & $\begin{array}{l}\text { Pidana denda sebesar Rp. } \\
5.000 .000 .000 .00\end{array}$ & $\begin{array}{l}\text { Pidana denda sebesar Rp. } \\
2.000 .000 .000 .00\end{array}$ & $\begin{array}{l}\text { Perkara } \\
\text { telah } \\
\text { didaftarkan } \\
\text { sejak 26 } \\
\text { november } \\
2014 \\
\text { dengan } \\
\text { durasi } 186 \\
\text { hari } \\
\end{array}$ \\
\hline & & & $\begin{array}{l}\text { Pidana tambahan: } \\
\text { Perbaikan akibat tindak } \\
\text { pidana untuk memulihkan } \\
\text { lahan yang rusak akibat } \\
\text { kebakaran lahan dengan } \\
\text { biaya sebesar Rp. } \\
1.046 .018 .923 .000 .00\end{array}$ & \begin{tabular}{l}
\multicolumn{3}{l}{ Pidana tambahan: } \\
Kewajiban melengkapi \\
sarana pencegahan dan \\
penanggulangan kebakaran \\
sesuai dengan petunjuk \\
standarisasi r sarana \\
pencegahan dan \\
penanggulangan kebakaran \\
hutan dengan pengawasan \\
Badan Lingkungan Hidup \\
Kabupaten Kepualauan \\
$\begin{array}{l}\text { Meranti jangka waktu } 1 \\
\text { tahun }\end{array}$
\end{tabular} & \\
\hline 8 & $\begin{array}{cl}\text { PT. Surya Panen Subur: } \\
\text { 1. } & \text { 54/Pid.Sus/2014/PN } \\
& \text { MBO tanggal 25 januari } \\
& 2016 \\
2 . & \text { 61/Pid.Sus/2016/PT BNA } \\
& \text { tanggal 12 juli 2016 } \\
3 . & \text { 267K/Pid.Sus/2016 } \\
& \text { tanggal } 9 \text { oktober } 2017 \\
\end{array}$ & $\begin{array}{l}\text { Pasal } \\
108 \text { UU } \\
32 / 2009\end{array}$ & $\begin{array}{l}\text { Pidana denda sebesar Rp. } \\
3.000 .000 .000 .00\end{array}$ & $\begin{array}{l}\text { Perkara telah didaftarkan } \\
\text { sejak } 7 \text { mei } 2014 \text { dengan } \\
\text { durasi } 631 \text { hari }\end{array}$ & \\
\hline
\end{tabular}


Data tabel 1 menunjukan bahwa penegakan hukum lingkungan hidup khususnya pertanggungjawaban korporasi memakan waktu yang lama dan belum berorientasi pada pemulihan. Selain itu, hanya 1 dari 8 perkara yang dijatuhkan sanksi pidana tambahan pemulihan kepada terpidana, 1 perkara sudah dijatuhkan pemulihan dalam perkara perdatanya ( PT Kalista Alam), dan 4 perkara dijatuhkan sanksi pidana tambahan pemberian kewajiban mengerjakan apa yang dilalaikan tanpa hak. Sanksi denda yang dijatuhkan pada terpidana lingkungan hidup memang sangat besar, rata-rata dari kedelapan kasus tersebut adalah Rp. 1.500.000.000.00, hal ini mengingat ancaman pidana yang tinggi dalam undang-undang karena dampak pencemaran atau kerusakan lingkungan hidup yang ditimbulkan juga besar. Namun perlu digarisbawahi bahwa sanksi pidana tidak dapat digunakan untuk pemulihan lingkungan hidup yang tercemar atau rusak, melainkan hanyalah penerimaan negara bukan pajak yang berlaku pada kejaksaan. Pengelolaan nya pun dilakukan oleh menteri. Pencemaran atau kerusakan lingkungan hidup yang berlangsung terus pun dapat menyebabkan kerugian ekologis dan ekonomi (interim loss) yang tidak sedikit. Singkatnya, penegakan hukum pidana korporasi dalam perkara lingkungan hidup belum berorientasi pada pemulihan (Daniel, Hawari, and Handayani 2019).

1) Teori Pemidanaan Berbasis Konservasi Lingkungan Hidup

Secara teoritik penentuan jenis pidana (straf sort), berat/bobot/lamanya pidana (straf maat) serta aturan pelaksanaan pidana (straf modus) harus didasarkan pada teori pemidanaan yang digunakan. Artinya, penggunaan teori tertentu berimplikasi pada penentuan ketiga hal tersebut. Teori pemidanaan yang sesuai sistem pemidanaan dalam perkara tindak pidana di bidang lingkungan hidup adalah teori pencegahan/penangkalan (deterrence).

Berdasarkan uraian diatas, teori pencegahan digunakan sebagai basis teoritis sistem pemidanaan berbasis konservasi lingkungan hidup didasarkan pada beberapa alasan. Pertama, dampak dan kerugian akibat tindak pidana lingkungan hidup sangat besar. Lingkungan hidup yang tercemar dan/atau rusak dapat mengakibatan terganggunya keseimbangan alam. Hal ini karena salah satu premis teori pencegahan adalah ancaman pidana lebih berat dari seriusitas tindak pidana.

Kedua, tindak pidana bidang lingkungan hidup dapat menimbulkan kerugian materiil tidak hanya bagi negara namun juga bagi masyarakat baik yang secara langsung atau tidak langsung terkena dampak. Lingkungan hidup yang tercemar dan/atau rusak harus diperbaiki dan diperbaharui sehingga dapat berfungsi sebagaimana mestinya seperti sebelum terjadinya pencemaran dan/atau perusakan lingkungan hidup. Upaya pemulihan dan pelestarian lingkungan hidup tersebut membutuhkan biaya. Jadi, ketika terjadi pencemaran dan/atau kerusakan lingkungan. 
Ketiga, motivasi pelaku tindak pidana bidang lingkungan hidup yang didasarkan pada kalkulasi untung rugi. Dengan kata lian, orientasi pelaku ketika ketika melakukan suatu perbuatan yang dilarang semata-mata didasarkan pada upaya untuk mendapatkan keuntungan ekonomis yang sebesar-besarnya. Tiap-tiap individu memilih apakah melakukan tindak pidana ataukah tidak melakukan tindak pidana.

Keempat, tindak pidana bidang lingkungan hidup seringkali dilakukan oleh orang yang bertindak untuk atau atas nama korporasi. Pada kasuskasus tindak pidana lingkungan yang dilakukan oleh korporasi, pertanyaan yang timbul adalah apakah perusahaan, pekerja atau keduanya yang harus dikenakan pidana? Sebuah pertanyaan penting dalam doktrin hukum pidana menyatakan bahwa sanksi pidana dalam praktiknya seharusnya dijatuhkan kepada korporasi.

Tindak pidana lingkungan yang dilakukan oleh badan usaha bertujuan untuk memperoleh keuntungan. Jadi, pidana harus menjadikan tindak pidana lingkungan menjadi lebih mahal (dari segi biaya) sehingga dapat mengurangi jumlah tindak pidana lingkungan. Hal ini disebabkan karena ketika pidana yang dijatuhkan kepada pelaku tindak pidana dapat menghambat diperolehnya keuntungan dari hasil tindak pidana tersebut oleh pelaku, pelaku tidak jadi melakukan tindak pidana (pidana berfungsi sebagai pencegah dilakukannya suatu tindak pidana) (Ali and Elvany 2014).

2) Bentuk dan Jenis Pemidanaan Berbasis Konservasi Lingkungan Hidup

Bagian penting dalam sistem pemidanaan adalah menetapkan suatu sanksi. Keberadaannya akan memberikan arah dan pertimbangan mengenai apa yang seharusnya dijadikan sanksi dalam suatu tindak pidana untuk menegakkan berlakunya norma. Penentuan jenis pidana, penjatuhan dan pelaksanaan pidana berhubungan erat dengan tujuan pemidanaan. Masalah penetapan penetapan sanksi dalam hukum pidana, apapun jenis dan bentuk sanksi apa yang paling tepat bagi pelaku kejahatan. Selain itu, sanksi yang diajtuhkan harus berorientasi sama dengan orientasi tindak pidana yang dilakukannya sehingga tujuan pemidanaan dapat tercapai. Peranan pidana dalam hukum lingkungan adalah sebagai daya paksa berupa injunction (untuk pemulihan lingkungan hidup) dan remedy (ganti rugi).

Peraturan perundang-undangan di bidang lingkungan hidup dibentuk dengan tujuan membela kepentingan lingkungan hidup, dan konsekuensinya, penegakannya juga seharusnya bertujuan untuk melindungi lingkungan hidup. Sanksi pidana sebagai salah satu sanksi yang diatur dalam peraturan perundang-undangan bidang lingkungan hidup harus ditetapkan dengan tujuan melindungi lingkungan hidup.

Sekalipun penjatuhan pidana penjara dimungkinkan bagi pelaku tindak pidana di bidang lingkungan hidup, namum pidana denda lebih diutamakan karena memiliki karakter yang ekonomis. Selain itu, kedudukan 
sanksi keuangan lebih tinggi dari sanksi non keuangan sehingga sanksi non keuangan seharusnya tidak digunakan kecuali sanksi keuangan tidak dapat melakukan pencegahan dengan baik. Sanksi non keuangan baru dibutuhkan untuk mencegah terjadinya tindak pidana ketika sanksi keuangan tidak cukup untuk tugas tersebut.

Masalahnya adalah denda dalam Undang - Undang bidang lingkungan hidup dibayarkan kepada negara tanpa ada kejelasan dan jaminan penggunaan denda yang dibayarkan oleh pelaku tindak pidana digunakan untuk konservasi lingkungan hidup atau tidak. Oleh karena itu, seharusnya ada klausul yang dapat menjamin penggunaan denda untuk membiayai konservasi lingkungan hidup, misalnya diatur dalam peraturan pemerintah sebagai aturan pelaksana dari Undang-Undang di bidang lingkungan hidup.

Dalam beberapa Undang-Undang dibidang lingkungan hidup, hakim dapat menjatuhkan tindakan langsug kepada pencemar yang dihukum, seperti kewajiban memperbaiki kerusakan yang telah dilakukannya. Pelaku tindak pidana pencemar air sungai jika dijatuhi pidana berupa memulihkan air sungai ke kondisi semula sebelum terjadinya pencemaran, ia dapat mengetahui betapa sulitnya mengembalikan kondisi air sungai ke keadaan semula. Ia juga dapat mengetahui rusaknya ekosistem air sungai secara langsung, seperti banyak ikan yang merupakan sumber penghasilan warga mati (Ali and Elvany 2014).

UU Konservasi-90 ditegaskan bahwa keberhasilan konsep ini ditentukan oleh tiga sasaran utama, yaitu:1) Apabila dapat menjamin terpeliharanya proses ekologis yang menunjang sistem penyangga kehidupan; 2) apabila dapat menjamin terpeliharanya keanekaragaman sumber genetik dan tipe-tipe ekosistemnya; dan 3) Apabila dapat mengendalikan cara-cara pemanfaatan sumber daya alam hayati sehingga terjamin kelestariannya (Silalahi 2014).

3) Aturan Pelaksanaan Pemidanaan Berbasis Konservasi Lingkungan Hidup

Dalam hal mekanisme pengaturan pidana denda. Pidana denda atau sanksi tindakan yang diatur dalam Undang - Undang di bidang lingkungan hidup membutuhkan suatu aturan pelaksanaan sanksi agar tetap menjamin pelaksanaan konservasi lingkungan hidup oleh pelaku tindak pidana meskipun pidana denda atau sanksi tindakan tidak dapat dibayar. Aturan pelaksanaan pidana dapat berupa perampasan aset bagi pelaku tindak pidana berupa badan usaha yang berbadan hukum, perampasan kekayaan dan dipailitkan bagi pelaku berupa badan usaha yang tidak berbadan hukum, serta pidana penjara bagi pelaku orang perorangan.

Pertama, aturan pelaksanaan pidana berupa perampasan aset berlaku bagi pelaku tindak pidana berupa badan usaha berbadan hukum, seperti perseroan terbatas dan yayasan yang tidak dapat membayar pidana denda. Aset di sini adalah kekayaan perusahaan baik berupa benda bergerak 
maupun benda tidak bergerak. Aset tersebut berasal dari modal yang di setor, dana cadangan, dan yang berasal dari hasil usaha perusahaan (keuntungan) yang bukan dividen (keuntungan perusahaan yang dibagikan kepada para pemegang saham).

Modal yang disetor merupakan modal perseroan berupa sejumlah uang tunai atau bentuk lainnya yang diserahkan para pendiri kepada kas perseroan pada saat perseroan didirikan. Dana cadangan merupakan sisa saham yang belum diambil dan menjadi saham simpanan atau saham tambahan modal, sehingga dapat dikeluarkan saham simpanan. Badan usaha melakukan kegiatannya demi mendapatkan keuntungan, tapi tidak semua keuntungan perusahaan dibagikan kepada para pemegang saham. Pembagian keuntungan tersbut dibahas dalam Rapat Umum Pemegang Saham (RUPS). Keuntungan perusahaan yang disetujui oleh RUPS untuk dibagikan kepada para pemegang saham disebut dengan dividen. Keuntungan yang tidak dibagikan kepada para pemegang saham menjadi aset perusahaan. Jadi, aset perusahaan yang dapat dirampas, baik berupa benda bergerak maupun benda tidak bergerak, berasal dari dana yang disetor, dana cadangan dan keuntungan non-dividen.

Kedua, aturan pelaksanaan pidana berupa perampasan kekayaan berlaku bagi pelaku tindak pidana berupa badan usaha yang tidak berbadan hukum, seperti persekutuan firma dan persekutuan komanditer. Ketika badan usaha tersebut dijatuhi pidana denda, sedangkan hartanya tidak cukup untuk membayar denda tersebut, para pemilik (sekutu) badan usaha bertanggungjawan untuk membayar sisa denda yang belum dibayar dengan harta kekayaan pribadi masing-masing secara tanggung renteng. Aturan ini berlaku bagi badan usaha berbentuk firma. Jika badan usaha berbentuk persekutuan komanditer, maka sekutu pasif hanya bertanggungjawab sebatas modal yang disetornya, sedangkan sekutu aktif bertanggungjawab secara pribadi secara keseluruhan. Jadi dalam persekutuan komanditer pihak yang bertanggungjawab untuk melunasi denda tersebut adalah sekutu aktif. Sedangkan sekutu pasif beratnggungjawab sebatas modal yang disetor.

Ketiga, pailit. Ia merupakan keadaan dimana suatu perusahaan sudah berada dalam keadaan berhenti membayar atau sudah tidak mampu lagi membayar utang-utangnya sehingga dijatuhi putusan pernyataan pailit dan penundaan pembayaran oleh pengadilan niaga baik atas permohonan kreditor maupun debitor atau pihak lainnya yang ditentukan oleh Undang Undang No.37 Tahun 2004 tentang Kepailitan. Kepailitan adalah suatu sita umum yang bersifat konservatoir atas semua kekayaan debitor yang dinyatakan pailit. Pihak yang dinyatakan pailit kehilangan penguasaan terhadap harta benda yang ia miliki.

Suatu badan usaha, baik badan usaha berbadan hukum maupun badan usaha tidak berbadan hukum, yang tidak dapat membayar pidana denda 
yang dikenakan terhadapnya dapat dimohonkan untuk dipailitkan ke Pengadilan Niaga. Berdasarkan Pasal 2 Undang-Undang Kepailitan, salah satu pihak yang dapat mengajukan permohonan kepailitan tersebut adalah kejaksaan negeri. Apabila permohonan kepailitan tersebut dikabulkan, badan usaha tersebut demi hukum kehilangan haknya untuk menguasai dan mengurus harta kekayaan yang ia miliki. Kekayaan tersebut menjadi harta pailit (boedel pailit).

Keempat, aturan pelaksanaan pidana denda berupa pidana penjara diberlakukan kepada orang perorangan yang tidak dapat membayar denda keseluruhan. Pidana penjara ini dijatuhkan kepada pengurus perusahaan dalam hal tindak pidana dilakukan oleh badan usaha berbadan hukum atau tidak berbadan hukum atau pihak lain yang menurut anggarasan dasar/anggaran rumah tangga perusahaan bertanggungjawab mewaikili perusahaan dalam perkara pidana. Pidana penjara juga dijatuhkan kepada orang perorangan yang melakukan tindak pidana di bidang lingkungan hidup (Ali and Elvany 2014).

Dengan demikian, dalam UUPPLH perlu diatur secara khusus dan tegas mengenai tujuan pemidanaan yang secara subtitutif mengintegrasikan tujuan pemidanaan perlindungan masyarakat untuk mencapai kesejahteraan dengan tujuan spesifik hukum lingkungan yang kesemuanya memberi landasan bagi pnetuan dan penerapan sanksi pidana alternative untuk tujuan pelestarian fungsi lingkungan guna mewujudkan pembangunan berkelanjutan sejalan dengan precautionary principle, pertanggungjawaban korporasi secara tersendiri, serta vicarious liability yang pada akhirnya tujuan pemidanaan guna mempertahankan pelestarian lingkungan hidup. Mekanisme dan jenis sanksi pidana perlu diatur dalam UUPPLH Nomor 32 Tahun 2009 sebaiknya tidak lagi hanya satu jenis yang bersifat imperatif kumulatif yaitu pidana penjara dikumulasikan dengan denda untuk semua jenis tindak lingkungan hidup dan dapat dikenakan pidana tambahan atau tindakan tata tertib, namun perlu diatur pidana alternatif yang lebih menekankan pada aspek ganti kerugian dan denda, dalam melakukan perbuatan yang sifatnya mengembalikan atau pemulihan kelestarian fungsi lingkungan serta tata tertib dalam tindak pidana lingkungan hidup dimasa yang akan datang sesuai dengan perkembangan pidana modern generasi ke empat, serta sesuai dengan sanksi denda dan ganti rugi yang lebih ditonjolkan dalam penindakan pencemaran dan perusakan lingkungan dalam kearifan lokal (hukum adat) yang masih berlaku di Indonesia. Untuk mengisi kekosongan hukum harapannya Mahkamah Agung RI dengan kewenangan rule power yang dimilikinya perlu membuat pedoman pemidanaan yang jelas sebagai kompas barometer, katalisator bagi hakim dalam menerapkan peraturan pidana lingkungan sehingga dapat emnjatuhkan pidana tersebut agar lebih adil, manusiawi, relative sesuai 
dengan keslahan pelaku tindak pidana, serta sekaligus guna menghindari putusan yang sangat mencolok. Serta tidak kalah penting perlu meningkatkan integritas moral dan pemahaman konfrehensif bagi aparatur penegak hukum khsusnya yang mengenai hakikat hukum lingkungan dengan tujuan pemidaan dan pedoman pemidanaan. Pelaksanaan eksekusi perkara lingkungan perlu melibatkan berbagai instansi terkait dan ahli, terutama dalam pencarian aset dan tindak pemulihan lingkungan. Dalam tindakan pemulihan perlu dibuat rencana pemulihan secara konkret dan valid serta ketika pembayaran denda ganti rugi dan biaya pemulihan lingkungan tidak dimasukkan dalam rekening kas negara, akan tetapi dibuat rekening khusus dan dipakai untuk penyelamatan kelestarian kepentingan lingkungan. Apabila uang ganti rugi pemulihan dimasukan ke dalam kas negara hal tersebut tidak memihak pada kelestarian lingkungan hidup karena yang terdampak dan rugi secara langsung itu bukan keuangan negara akan tetapi lingkungan hidup. Setiap langkah penegakan hukum dalam perkara lingkungan hidup wajib dilakukan terobosan hukum dengan cara melakukan Judicial Activism.

\section{Kesimpulan}

Dari hasil pembahasan diatas dapat disimpulkan bahwa, terdapat kelemahan norma dan sanksi dalam peraturan lingkungan hidup sebagaimana dalam UUPPLH Nomor 32 Tahun 2009, yang mana tidak menggambarkan secara jelas mengenai tujuan pemidanaan yang dapat dijadikan patokan dalam menetapkan sanksi pidana yang dilandasi dengan ide - ide dasar. Dalam hal ini, sangat sulit melihat koherensi tujuan pemidanaan dengan tujuan pelestarian fungsi lingkungan hidup. Selanjutnya sanksi pidana yang diatur dalam UUPPLH Nomor 32 tahun 2009, hanya satu jenis yaitu pidana penjara dikumulasikan dengan denda diterapkan terhadap semua jenis tindak pidana lingkungan hidup dan dapat dikenakan pidana tambahan atau tindakan tata tertib apabila tindak pidana dilakukan oleh badan usaha (korporasi). Pengaturan jenis sanksi demikian tanpa pengaturan secara alternative akan berdampak dalam praktek pemidanaan berupa tuntutan dan penjatuhan pidana umum sebagaimana diatur dalam KUHP, belum menyentuh tujuan hukum lingkungan itu sendiri yang mana berfungsi sebagai acuan pemanfaatan dan pencadangan sumber daya alam serta pelestarian lingkungan hidup sehinga pemanfaatan sumber daya alam dapat berjalan secara berkelanjutan. 


\section{BIBLIOGRAFI}

Akib, Muhammad. 2014. Hukum Lingkungan Persfektif Global Dan Nasional. Jakarta: Rajawali Pers.Google Scholar

Ali, Mahrus. 2019. Overcriminalization, Teori, Dampak \& Pencegahan. Yogyakarta: FH UII Press. Google Scholar

Ali, Mahrus. 2020. Hukum Pidana Lingkungan. Depok: Penerbit Rajawali Pers.

Ali, Mahrus, and Ayu Izzan Elvany. 2014. Hukum Pidana Lingkungan: Sistem Pemidanaan Berbasis Konservasi Lingkungan Hidup. UII Press. Google Scholar

Amrani, H. 2019. Politik Hukum Pembaharuan Hukum Pidana. Yogyakarta: UII Press.

Bram, Deni. 2014. Politik Hukum Pengelolaan Lingkungan Hidup. Malang: Setara Press. Google Scholar

Daniel, Deni, Azam Hawari, and Marsya Mutmainah Handayani. 2019. "Reorientasi Penegakan Hukum Pidana Lingkungan Hidup Melalui Perjanjian Penangguhan Penuntutan.” Jurnal Hukum Lingkungan Indonesia 6(1): 72-96. Google Scholar

Daniel, Deni, Azam Hawari, and Marsya Mutmainah Handayani.. 2020. "Reorientasi Penegakan Hukum Pidana Lingkungan Hidup Melalui Perjanjian Penangguhan Penuntutan.” Jurnal Hukum Lingkungan Indonesia 6(1): 72-96. Google Scholar

Husin, Sukanda. 2014. Penegakan Hukum Lingkungan Indonesia. Jakarta: Sinar Grafika. Google Scholar

Joni. 2020. Aspek Pidana Dan Ganti Rugi Pencemaran Lingkungan Lintas Negara. Yogyakarta: Pustaka Pelajar. Google Scholar

Margaretha, Mas Achamad Santosa \&. 2014. "Hukum Lingkungan." Quina,Jurnal Vol(Issue 1).

Muhammad Erwin. 2015. Hukum Lingkungan Dalam Sistem Perlindungan Dan Pengelolaan Lingkungan Hidup Di Indonesia. Bandung: Rafika Aditama. Google Scholar

Rahmadi, Takdir. 2019. Hukum Lingkungan Di Indonesia. Depok: Rajawali Pers. Google Scholar

Raynaldo Sembiring, Marsya M.Handayani, Boy Even Sembiring. 2019. "Rkuhp: Melemahkan Gakkum Pidana Lingkungan.” In Icel.

Raynaldo Sembiring, S.H., Yustisia Rahman, S.H., Elizabeth Napitupulu, S.H., Margaretha Quina, S.H., Rika Fajrian. 2014. Anotasi Undang - Undang Nomor 32

Tahun 2009 Tentang Perlindungan Dan Pengelolaan Lingkungan Hidup. Jakarta: 
Ryan Akbar Fitriadi

ICEL.

Silalahi, M. Daud. 2014. Hukum Lingkungan Dalam Sistem Penegakan Hukum Lingkungan Indonesia. Bandung: PT Alumni. Google Scholar

Wibisana, Laode M.Sayrif \& Andri G. Hukum Lingkungan, Teori, Legislasi Dan Studi Kasus.

Zairin Harahap. 2020. Penegakan Hukum Lingkungan. Yogyakarta: UII Press.

Copyright holder :

Ryan Akbar Fitriadi (2021)

First publication right :

Syntax Idea

This article is licensed under:

(c) (i) (O) 